\title{
Mapping Food Production in Hyper-Arid and Arid Saharan Africa in the Holocene-A View from the Present
}

\author{
Carla Lancelotti $1,2, *$ (D) and Stefano Biagetti ${ }^{1,3}$ (D) \\ 1 CaSEs Research Group, Department of Humanities, Universitat Pompeu Fabra, c/Trias Fargas 25, \\ 08005 Barcelona, Spain; stefano.biagetti@upf.edu \\ 2 ICREA, Passeig Lluís Companys 23, 08010 Barcelona, Spain \\ 3 School of Geography, Archaeology and Environmental Studies (GAES), University of the Witwatersrand, \\ 1 Jan Smuts Ave, Johannesburg 2000, South Africa \\ * Correspondence: carla.lancelotti@upf.edu
}

Citation: Lancelotti, C.; Biagetti, S. Mapping Food Production in Hyper-Arid and Arid Saharan Africa in the Holocene-A View from the Present. Quaternary 2021, 4, 13. https://doi.org/10.3390/ quat4020013

Academic Editor: Marc Vander Linden and Philip Riris

Received: 29 March 2021

Accepted: 13 April 2021

Published: 22 April 2021

Publisher's Note: MDPI stays neutral with regard to jurisdictional claims in published maps and institutional affiliations.

Copyright: (c) 2021 by the authors. Licensee MDPI, Basel, Switzerland. This article is an open access article distributed under the terms and conditions of the Creative Commons Attribution (CC BY) license (https:/ / creativecommons.org/licenses/by/ $4.0 /)$.
Abstract: The reconstruction of land use practices in hyper-arid Saharan Africa is often hampered by the accuracy of the available tools and by unconscious biases that see these areas as marginal and inhospitable. Considered that this has been for a long time the living space of pastoral mobile communities, new research is showing that agriculture might have been more important in these areas than previously thought. In this paper, after a review of present-day land use strategies in Saharan Africa, we show how ethnographic and ethnoarchaeological data can offer us a different point of view and help in better defining land use and food production strategies in this area. Ultimately, these insights can be integrated into the ongoing efforts to reconstruct past land use globally.

Keywords: drylands; land use; aridity index; ethnography; ethnoarchaeology; pastoralism; agriculture; LandCover6K

\section{Introduction}

The Sahara is the largest hot desert on Earth. It includes a variety of ecological and environmental settings, such as rocky plateaus, mountains, dune fields, (mostly dried) river valleys, and stony surfaces (hamada/serir). Like all deserts, it has always evoked images of an inhospitable land, devoid of resources, where human life is harsh at the least; a place where only a few tribes of seasoned mobile societies could win over the barren land and make it their home. In this empty landscape, the presence of water in the form of rivers or oases has always been seen as the lifeline providing coveted places of abundance and life. Indeed, the Sahara is so overlooked as a place for human life that in modern geopolitics, the African continent is divided into "North Africa" and "sub-Saharan Africa", both including countries whose territory falls almost completely within the limits of the desert ecosystem. However, the capitals of these countries, as well as the living places for the dominant elites in the past, are all close to fresh water, either alongside major rivers or at the margins of the desert, where annual precipitations increase, the vegetation cover becomes more abundant, and the land can be fully cultivated. Thus, the desert as a space for living disappears from many narratives, to remain associated with a land to cross, the home of pastoral mobile societies or a few, small sedentary communities living in the oases. In this paper, we transcend the qualitative, social and geographical definitions and we overcome the dichotomy of North versus sub-Saharan Africa by capitalizing on a climatic index, the Aridity Index (AI), which classifies territories according to the ratio between rainfall and potential evapotranspiration [1,2]. After a general consideration of past and present land use in the Sahara, we report on modern and historic examples of three specific forms of land use within extremely arid areas characterised by an AI up to 0.07 (Figure 1), specifically pastoralism, oasis agriculture and rainfed agriculture. Ultimately, starting from ethnographic observations and models, we will discuss how to extend land 
use classification in the past for these specific cases, by applying the recent framework developed by the PAGES LandCover6K initiative $[3,4]$. The goal of this international effort is to combine a wide array of proxies to reconstruct past land cover and land use changes to improve current climatic models. Previous research has shown how the current reconstruction of past land cover and land use are highly dependent on our ability to correctly identify such practices in the past [4]. Thus, the data presented in this paper might serve as a baseline on which to build more precise models of land use in hyper-arid areas in the future.

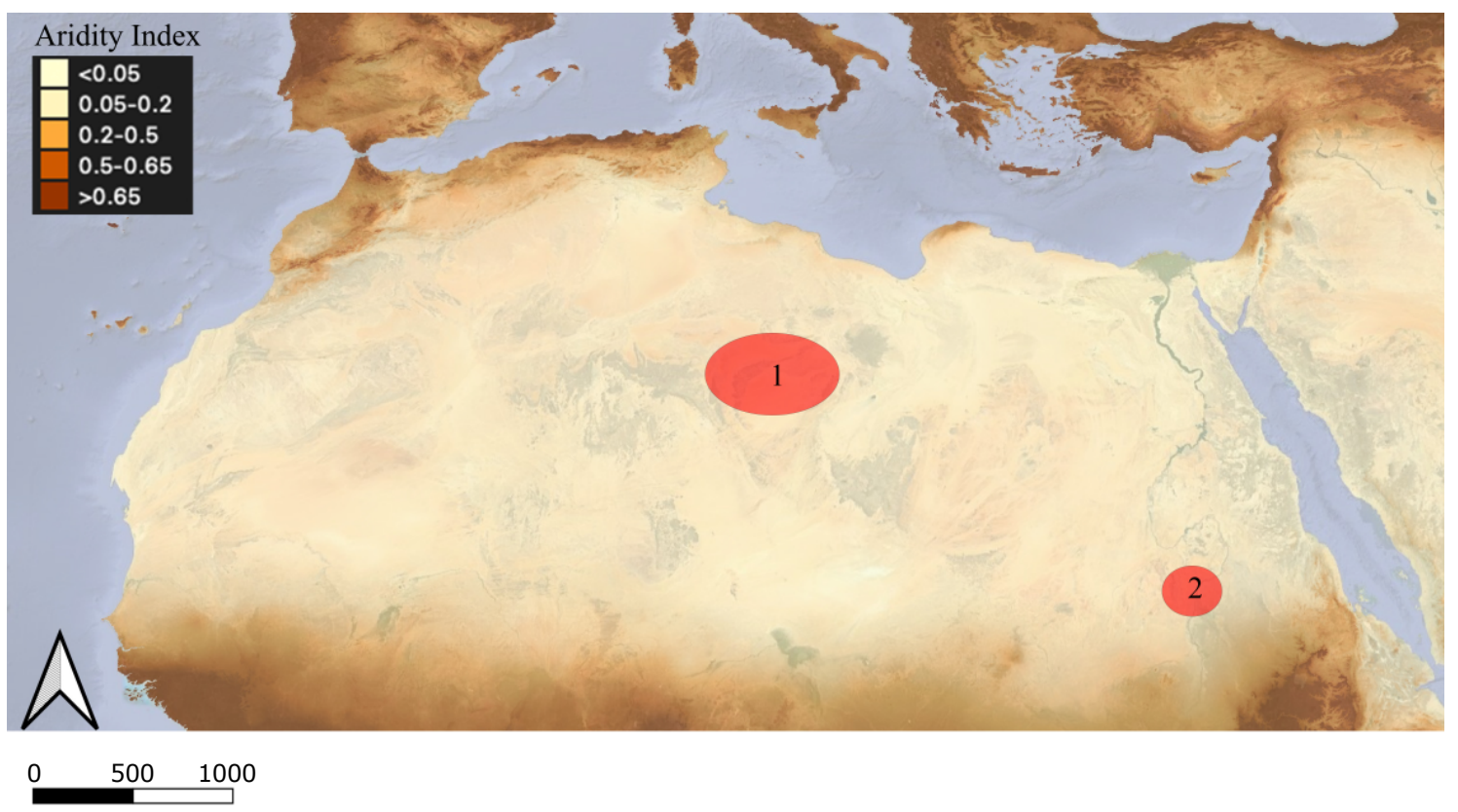

Figure 1. Aridity Index [1,2] map of the area considered in this study: (1) Fazzan; and (2) Central Sudan. Note that by using this index, our use of the term "Sahara" also encompasses areas that are not normally considered part of this desert, such as the Nile Valley and coastal areas of Egypt (map elaborated with QGIS-LTR 3.16).

\subsection{Overview of Past Land Use in the Holocene Sahara}

The Fazzan in SW Libya and the Nile Valley are probably the best-known areas in the Sahara and North Africa. Both regions have attracted multidisciplinary teams of archaeologists, biologists, and geologists that, from the 19th century onward began to explore their past. As a result, these stand out as some of the few areas of the Sahara where long sequences of occupations have been reconstructed for the last 10k years [5,6]. Current reconstructions suggest that from 7 kya onward, pastoralism was the only form of food production adopted in Fezzan, up to c. 3 kya, when cultivation was introduced into the oases [7]. Pastoralism in this view represents the earliest form of food production in the Sahara, and its development was largely affected by Holocene climatic shifts. In North Africa and the Sahara, the general trend toward present day aridity began around $5 \mathrm{kya}[8,9]$. Post $5 \mathrm{k}$ aridification was a main driver in opening new pastures to domestic livestock, fostering the diffusion of pastoralism into sub-Saharan Africa [10]. Nevertheless, the Sahara was not abandoned $5 \mathrm{kya}$, and pastoral societies responded to climate change with the adoption of different types of stock and changing their settlement patterns [11,12]. Since the adoption of domesticated animal (c. $7 \mathrm{kya}$ ), African pastoralists were able to cope with variations in yearly rainfalls, not dissimilarly to what current pastoral societies do $[13,14]$. Such climatic variability likely prompted the adoption of flexible strategies of land use from 5 kya onwards [11]. The work of both British and Italian teams (1990-2011), with the support of Libyan institutions and colleagues, has shed light on the Garamantes, notably the earliest state of the Sahara. Through these data, oasis agriculture in the Fazzan is dated to c. 3 kya (for a recent review, see [7]) and featured the use of foggaras (qanats) 
underground channels and dug wells. Foggaras were likely introduced in Garamantian times during the last centuries BC and were in use until the medieval period, and probably no later than the end of the first millennium AD [15]. With the advent of the Garamantian age (c. 3000-1400 years ago), oasis cultivation and long-range pastoralism became the main components of a mixed system that lasted practically up to modern times [16]. Recent research $[7,17]$ has demonstrated that the oases of the Fazzan were intensively exploited by agriculturalists, and in some cases, densely inhabited as early as Garamantian times (BC1000-700AD, c. 3 k-1.4 kya) [18].

\subsection{Present Day Land Use in Saharan Africa}

Our understanding of land use in Saharan Africa is, at present, driven by two main constraints: the availability of data and models and the focus, in the research effort, to ensure food stability in drylands, on crops and cropland. The constant improvement of satellite and remote sensing data has allowed the creation of multiple datasets and models that are currently used, principally to monitor land cover and derive cropland potential at both the regional and global levels (for a complete list see, $[19,20])$. One of the latest among these, the NASA Making Earth System Data Records for Use in Research Environments (MEaSUREs) Global Food Security-Support Analysis Data (GFSAD) product, provides global cropland extent data for the year 2015 at $30 \mathrm{~m}$ resolution [21]. Recent research has compared this and other datasets to understand the level of agreement between them, at the global and regional levels (see for example [19,20,22]). These studies highlighted a certain lack of agreement between the various datasets, which is particularly significant in certain areas. For example, Pérez-Hoyos and colleagues [20] found that, over nine different datasets, full agreement is reached in the whole of Africa only in $2.15 \%$ of cases. Conversely, there are areas, such as the Nile delta in Egypt, where full or high agreement (6-8 out of 9 datasets) is reached in a surprisingly high percentage of cases (42.6\% of cases) ([20] p. 11 and Figure 1). A similar study that concentrates only on Africa reached almost identical conclusions and highlighted that inconsistencies in crop mapping are particularly significant in the Sahel and in West Africa [19]. All these studies seem to agree on the fact that the Sahara is mostly bare, mainly based on the seminal landcover publication of the FAO that characterises the entire Sahara as bareland [23].

The main problems associated with cropland definition at the global and regional levels are determined by gaps in the baseline information, the lag between research and operational implementation, cloud cover, resolution, and data updating amongst others [22] Specifically for Africa , Nabil and colleagues [19] stress the limitations due to cell resolution, highlighting that the use of a $30 \mathrm{~m}$ resolution image size is not enough to detect a small $(<1.5 \mathrm{ha})$ and very small ( $<0.15 \mathrm{ha})$ parcel size, which mainly characterise agricultural land in Africa and suggest that the ideal resolution would be between 5 and $10 \mathrm{~m}$. Amongst the available datasets, the Spatial Production Allocation Model (SPAM) uses a different array of inputs to provide plausible estimates of crop distributions within disaggregate units, for 42 crops and different cultivation strategies (irrigated, rainfed, high/low input, etc.) and it has the advantage of being updated every five years [24]. According to the latest version of this dataset [25], the irrigated and rainfed cultivated area in North and Saharan Africa can be seen in Figure 2. Based on these estimates, cultivation in the Saharan belt is mainly based on rainfed practices (Figure $2 b$ ) and the main products are tropical fruit (most probably date palms) and in some small instances, wheat, barley and rice are cultivated in the desert, whereas sorghum and vegetables are prevalent along the Nile. Interestingly, there seems to be no record of the rainfed cultivation of pearl millet, which was the main crop we observed during fieldwork [26]. 


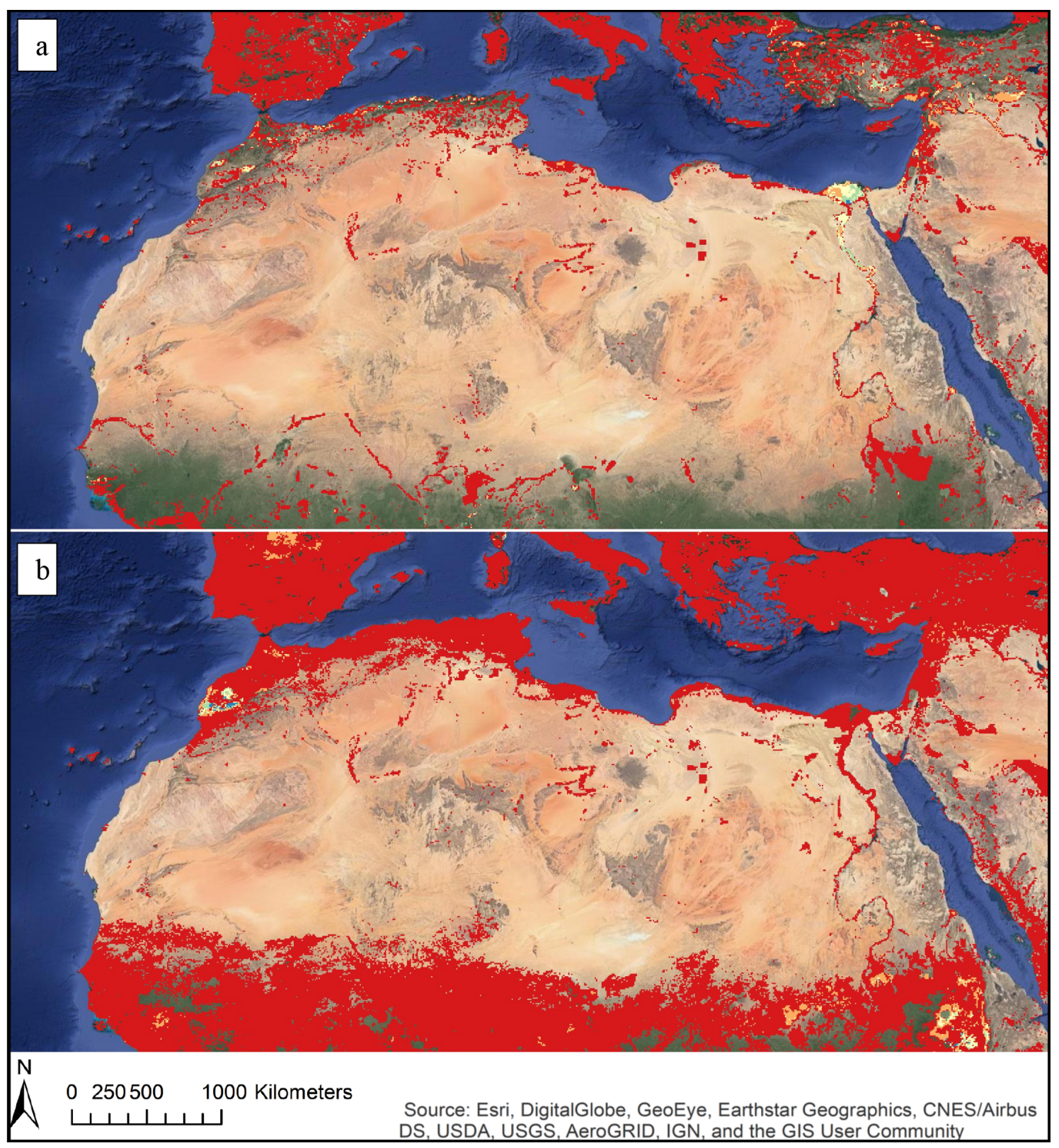

Figure 2. Aggregated maps for all 42 crops produced using Harvest Choice data [25]: (a) total area irrigated; and (b) rainfed. Areas in red show the presence of the cultivation of at least one crop at the lower end of the scale. Areas not shaded indicate that no data are available. Zeroes (cells where there are available data but no cultivation) have been removed (maps elaborated with ArcGIS).

The aforementioned issues also affect the reconstruction of grazing lands and pasture areas. Phelps and Kaplan [27] have recently pinpointed the difficulties in the study of pastoral land use. Along with the intrinsic problems in defining both terms, the authors indicate that the attempts at classifying land use for pastoral uses have mostly been performed on remotely collected data (e.g., [28,29]) or on available inventory data (e.g., [23]). Only a few approaches have adopted a combination of both datasets [30,31]. The classification of pastoral land use is largely based on the identification of natural vegetation (land cover) in areas where agriculture is allegedly neither practised nor practicable. Therefore, as an indirect measure of potential pastoral land use, the various definitions of pastureland and grazeland largely depend on the capacity to detect such a patchy vegetation canopy, typical of hyper-arid and arid areas. Remotely sensed land cover reconstructions, in fact, can hardly capture such erratic "natural" vegetation (see [32]), where shrubs often rep- 
resent the base of livestock nourishment [16]. Not surprisingly, following the previously mentioned classification of the FAO [23], most of the Sahara is classified as treeless and barren by those engaged with the design of remotely sensed land use models through time (e.g., [31,33]) (Figure 3). To overcome this limitation, Phelps and colleagues [10] provided maps of climate suitability for animal husbandry at 500-year intervals for the last $10 \mathrm{k}$ years, focusing on the modelling of niches suitable to pastoralism at the continental level. This work represents an exceptional attempt at modelling the extent of areas suitable for pastoral societies in Africa.

In the next section, we will show how ethnoarchaeological data, both extracted from ethnographic observations produced between the end of the 19th and the beginning of the 20th century, as well as collected more recently, can provide valuable insights for land use in hyper-arid and arid areas.

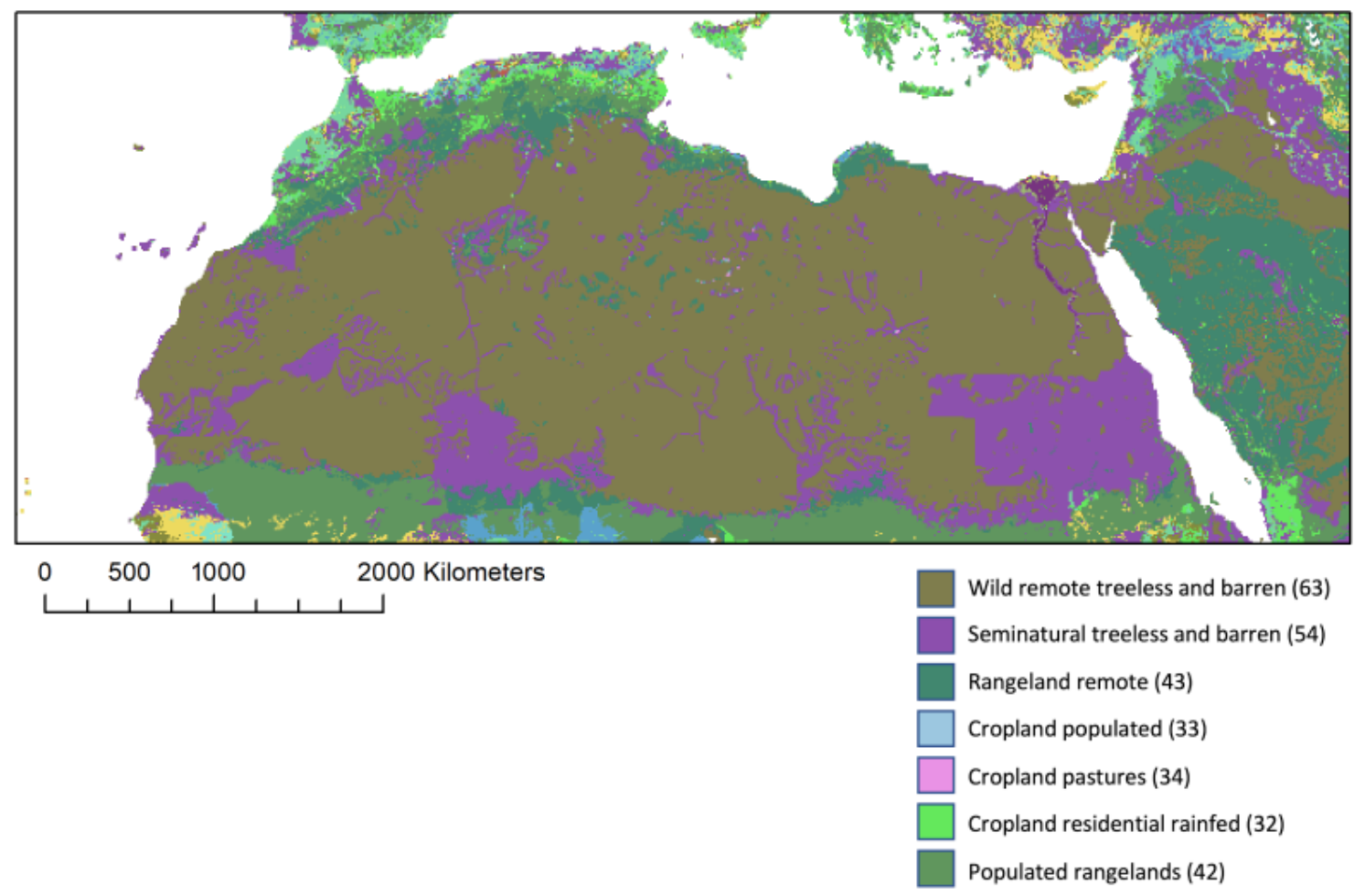

Figure 3. Elaboration from data published by Klein Goldewijk, Dr. ir. C.G.M. (Utrecht University) [33]. Anthropogenic land-use estimates for the Holocene; HYDE 3.2. DANS. Legend displays the original classification of the anthromes (with numbers) as proposed by Ellis and Ramankutty [34]. The legend includes the most represented anthromes as visible in the map (map elaborated with ArcGIS).

\section{Methods}

Data on historic pastoral land use were extracted from the available ethnographic literature [16,35-39] and from the HYDE 3.2 model [33]. Modern day data on agricultural production were mainly derived from the Harvest Choice database [25]. Ethnographic fieldwork was carried out in different seasons: in Fazzan between 2003 and 2011 [16] and in Central Sudan in 2015, 2016 and 2019 [40]. The classification of land use followed the PAGES LandCover6k categories, which are organised hierarchically. The first level (Land Use 1, LU1) represents a global level of land use and the second (LU2) a regional one [3].

\section{Three Examples of Present and Modern Land Use in Arid and Hyper-Arid Sahara: Pastoralism, Oasis Agriculture and Rainfed Agriculture}

In this paper, we concentrate on the Fazzan in SW Libya and the Nile Valley, which are probably the best-known areas in the Sahara and North Africa. Both regions have attracted 
multidisciplinary teams of archaeologists, ethnographers, biologists, and geologists that, from the 19th century onward began to explore their past and present. As a result, these stand out as some of the few areas of the Sahara where long sequences of occupations have been reconstructed for the last $10 \mathrm{k}$ years $[5,6]$. Current reconstructions suggest that from 7 kya onward, pastoralism was the only form of food production adopted in Fezzan, up to c. 3 kya, when cultivation was introduced in the oases [7]. Pastoralism in this view represents the earliest form of food production in the Sahara, and its development was largely affected by Holocene climatic shifts. In a comparable manner, Holocene climatic fluctuations largely affected the social dynamics and the development of food production in the Nile Valley [6], where the exploitation of a broad range of resources characterised past societies between the tenth and the sixth millennia BC [41]. Standing as a long green strip crossing the eastern part of the Sahara, the Nile represented a center of attraction for past human communities gravitating around it. Farming was considered, up to recent times, to date back to 5200 BC in the Fayum area [42], and to have reached Sudan a few centuries later [41,43]. In the Nilotic Nubian Neolithic (4500-3000 BC), subsistence was based on fishing and pastoralism, integrated with harvesting wild sorghum and millet [44]. Wild sorghum was likely cultivated $[45,46]$, while emmer and barley, both of Near Eastern origin, were adopted as far south as Al Khiday [47]. Connections between the Central Sahara and the Nile Valley were recognised by Arkell as early as the beginning of the 20th century [43]. In both regions, the advent of food production occurred during the Middle Holocene (c. $7 \mathrm{k}$ years ago) and was later propelled by the advent of more arid conditions $5 \mathrm{k}$ years ago that, in turn, paved the way to the rise of social stratification [6].

\subsection{Pastoralism}

It is nowadays widely acknowledged that pastoralism represents a suitable practice to achieve food security in semi-arid to hyper-arid environments, due to its flexibility and adaptability to changing natural resources (both in time and in space). Pastures and rangelands represent the most extensive form of land use, adding up to a quarter of the Earth's ice-free land surface ([27], and references therein), although the quantification and classification of pastureland or rangeland has proven to be a difficult task (see Section 2). On the other hand, ethnographic accounts can provide important insights on the past and recent land use of pastoral societies, though the majority of pastoral landscapes have been cartographed as a series of points connected by arrows, thus displaying the year round cycles of movements of a given society [48]. In terms of land use reconstruction, this type of information is intrinsically problematic, as it does not convey the extent of the territory used by pastoralists at the time of the generation of the map. Aware that any cartography of pastoralists, especially in drylands, is an indicative tool that can portray some coarse contours including customary lands used by pastoralists, we will discuss here the case of the Fazzan, where records compiled as a consequence of military administration from the 1930s, coupled with direct field observation by one of the authors (SB), to provide additional insights about recent and current land use.

Pastoral activities during the 1930s, as reported in colonial era accounts, covered vast areas of SW Fazzan. All five areas included in the reports (see Table 1) represent important hotspots in the region, and host oases and towns. Along with sedentary settlements, Tuareg and Tebu nomads have traditionally grazed their livestock in these areas. In the 1930s, the accurate census of the nomadic and sedentary groups was carried out under the Italian and, later, French administrations. The Italians [35-37] collected precise data on the nomadic herders and their customary grazing areas (see Figure 4 and Table 1). Tuareg and Tebu from the Fazzan roamed through hyper-arid locations (Figure 4b), where only a few spots of "grazing areas" have been identified by the HYDE 3.2 land use map (Figure $4 \mathrm{c}, \mathrm{d}$ ). The authors refer to those herders as nomadic, and hint at some differences in their patterns of yearly movements [35-37]. Those living in areas 4 and 5 looked more prone to longer transhumances, while those living in the large Wadi Shati (area 1), Wadi el Ajal (area 2), and Wadi Berjuj (area 3) were characterised by more regular movements, 
though still opportunistic and variable, which may explain the occurrence of "other" stock, mainly poultry, that fit with a semi-nomadic lifestyle. Allegedly, pure nomads were raising only ovicaprines (OC in Table 1) dromedaries, and, in the case of the Tuareg living in the area of wadi Tanezuft (area 5) also some donkeys (Equines in Table 1). Field research in the Tanezuft area reported the presence of contemporary Tuareg pastoralists in the area, exploiting the episodic pastures that are to be found along the wadis [16]. Similarly, field trips to Wadi el Ajal and Wadi Berjuj confirmed the persistence of pastoralism, although a general trend toward a progressive sedentarisation —already stressed in the 1930s-was noticed [16]. In the 2000s-2010s, until the 2011 turmoil, pastoralism in these areas was characterised by strong opportunism. Families of herders exploited customary grazing areas and were ready to move to more distant pastures in cases of good rain. Flexible movements and rapid decisions represent the key to thrive in the Fezzan, where the climate is hyper-arid with almost no rainfall (ranging between 0 and $20 \mathrm{~mm}$ per year) and the natural resources for livestock (water and pastures) are erratic and patchy.

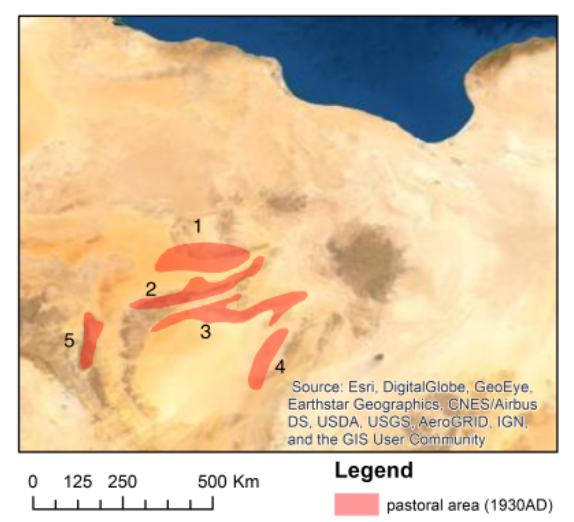

a

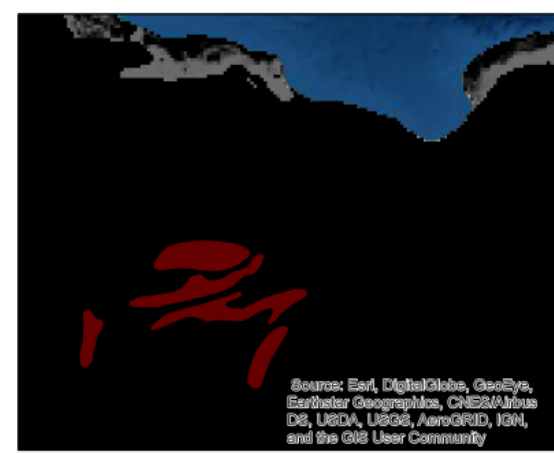

$0 \quad 125 \quad 250$

$500 \mathrm{Km}$

Legend

pastoral area (1930AD)

C Value

${ }_{\text {High : }} 83.8902$

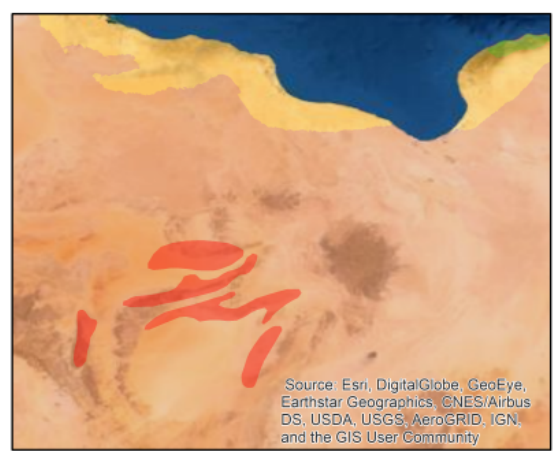

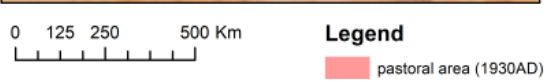

b

Aridity Index

$\square<0.05$ (hyp.-ar.

$\square$
$\square \quad 0.2-0.5$ (semi-ar.)

0.5-0.65 (dry s.-hum.)

$>0.65$ (humid)

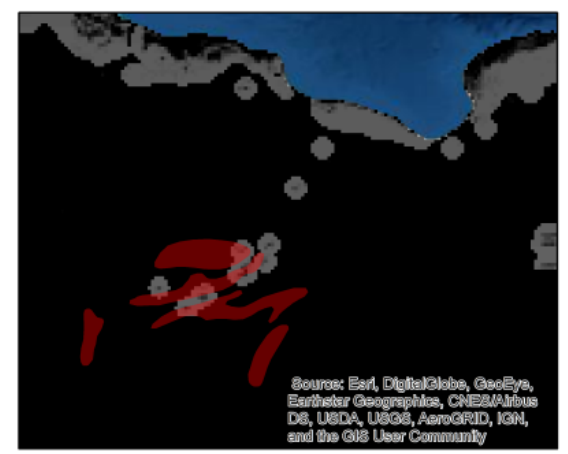

\section{\begin{tabular}{llll}
\hline & 125 & 250 & $500 \mathrm{Km}$
\end{tabular}}

pastoral area (1930AD)

d grazing1930AD.asc

Value

Hign: 85

Figure 4. Pastoral areas in Fezzan (area 1 in Figure 1) according to ethnographic sources [35-37]: (a) the five areas discussed in this paper, key: 1-Wadi Shati, 2-Wadi el Ajal, 3-Wadi Berjuj, 4Wadi Hikma, and 5-Wadi Tanezuft; (b) in relation to the Aridity Index values; (c) superimposed to rangeland values; and (d) superimposed to grazing values. Legend in (c,d) displays the land use according to Klein [33]. Spatial resolution 5 arc-minutes (maps elaborated with ArcGIS). 
Table 1. Demographic, land use and livestock data in the areas of the Fazzan in the 1930s [35-37]. For the location of the areas, see Figure 4. LU1 = Land Use level 1; LU2 = Land Use level 2; OC = ovicaprines; Equines = horses and donkeys.

\begin{tabular}{|c|c|c|c|c|c|c|c|c|c|c|}
\hline Area & Group & LU1 & LU2 & Area $\left(\mathrm{km}^{2}\right)$ & People & Dromedaries & OC & Equines & Cattle & Others \\
\hline 1 & Tuareg & Pastoralism & Mobile-irregular & 15,641 & 4106 & 1214 & 865 & 339 & 0 & 300 \\
\hline 2 & Tuareg & Pastoralism & Mobile-irregular & 12,396 & 611 & 335 & 375 & 48 & 0 & 150 \\
\hline 3 & Tuareg & Pastoralism & Mobile-irregular & 15,619 & 280 & 150 & 340 & 0 & 0 & 50 \\
\hline 4 & Tebu & Pastoralism & Mobile-irregular & 7286 & 260 & 240 & 410 & nd & 0 & nd \\
\hline 5 & Tuareg & Pastoralism & Mobile-irregular & 5463 & 500 & 509 & 1137 & 308 & 25 & nd \\
\hline
\end{tabular}

\subsection{Oasis Agriculture}

Oasis agriculture in Fazzan is dated back to as early as c. 3 kya (for a recent review see [7]), and was practised with traditional technologies until very recently. Ethnographic studies of local agricultures were carried out under the French and the Italian colonial administrations [35-37,39]. In the first half of the 20th century, those authors reported that the Fazzani oases presented favorable characteristics for the cultivation of crops. In fact, the water table was generally shallow. Scarin [35] noticed that in many areas, the water table could be reached only a few meters below the surface. Therefore, traditional shallow wells were reported in use during 1930s and 1940s [35,39], representing the sole method for irrigating fields, being the ancient foggaras abandoned in historical times. Some colonial age publications report precise data on the list of species cultivated and their number in each oasis [35-37] (Table 2. Oasis agriculture is described as being dependent on well irrigation, although in some cases (e.g., in the Wadi el Ajal), portions of the ancient foggaras were still in use [38]. Fazzani gardens are generally square or rectangular, with sides that range between 30 and $200 \mathrm{~m}$. Every garden is crossed by a network of shallow irrigation channels made of mud. In the 1930s, the majority of those gardens were owned by some prominent families, who employed wage workers. Small holders, mainly former nomadic Tuareg or Tebu, owned smaller gardens and were running family enterprises with no employees. The gardens were being cultivated with palm trees (Phoenix dactylifera L. arabic Nachla), providing dates and plant material for crafting basketry, beds, saddles, and for construction as well. Palm trees in the Fazzani gardens did not need irrigation since the water table was often shallower than $5 \mathrm{~m}$. Along with their byproducts, palm trees provided shade to wheat (Triticum vulgare Vill. in the original text, syn. T. aestivum L.) and barley (Hordeum vulgare L.) during winter and sorghum and millet (Pennisetum americanum (L.) Leeke in the original text syn. Chenchrus americanum (L.) Morrone), along with legumes and vegetables. Occasionally, those reports are associated with some sketches of selected oases $[35,36]$, that allow us to reconstruct the extent of the inhabited area and the size of the cultivated areas (Table 2).

Table 2. Demographic, land use and crop data for selected oases in the Fazzan in the 1930s [35-37]. For the location of the oases, see Figure 4. LU1 = Land Use level 1; LU2 = Land Use level 2; areas are expressed in ha; garden area includes settlement area. * system formed by three oases Tamzaua-Es Zueia-Zeluaz.

\begin{tabular}{|c|c|c|c|c|c|c|c|c|c|}
\hline Area & Oasis & LU1 & LU2 & People & Mobility & Settlement Area & Garden Area & Palms & Pams/Pax \\
\hline 1 & Brak & Agriculture & Annual crops & 730 & Sedentary & 5.9 & 54 & 17,000 & 23 \\
\hline 1 & Tamzaua * & Agriculture & Annual crops & 1329 & Sedentary & 23.74 & 1200 & 22,600 & 17 \\
\hline 2 & Greifa & Agriculture & Annual crops & 541 & Sedentary & 14.5 & 50 & 3000 & 6 \\
\hline 2 & Brach & Agriculture & Annual crops & 257 & Sedentary & 5 & 69 & 7800 & 30 \\
\hline 2 & El Abiad & Agriculture & Annual crops & 266 & Sedentary & 0.9 & 9 & 2800 & 23 \\
\hline 4 & El Gatrun & Agriculture & Annual crops & 404 & Sedentary & 24 & 160 & 39,000 & 97 \\
\hline 4 & Tegerhi & Agriculture & Annual crops & 140 & Sedentary & 1.1 & 90 & 7000 & 50 \\
\hline
\end{tabular}

\subsection{Rainfed Agriculture}

For the purpose of this paper, we considered rainfed agriculture as the cultivation of domestic or semi-domestic crops that rely exclusively on rain, where no additional water (irrespective of its origin) is provided to the plants before or during the growth period, which is practised far from rivers or water basins that can create a flooded area during 
the rain period. The crops that can be cultivated with this kind of agricultural practice are obviously dependent on the environment where they are grown with wetter areas providing better ground for this practice. Rainfed agriculture is usually deemed unviable in areas that receive less than $300 \mathrm{~mm}$ of annual rainfall in the absence of water harvesting structures [49] even when considering drought-tolerant crops such as millets and sorghum, which not only require less water than other crops (such as wheat, barley, rice and maize) but also have shorter growing periods, making them better adapted to grow in drylands. As Figure 2 shows, rainfed agriculture is extremely limited in Saharan Africa and is mainly concentrated in the Sahel, on the northern coast and along the banks of the River Nile, that is in areas with higher rainfall (and Aridity Index values) or on the floodplain of a major river. Between 2015 and 2019, the authors conducted ethnoarchaeological surveys in the area south of Omdurman on the west bank of the White Nile within the frameworks of the Al Khiday (directed by D. Usai and S. Salvatori [50]) and the RAINDROPS projects. At present, this area can be classified as borderline hyper-arid, with an Aridity Index of 0.07. Here, we recorded several instances of the rainfed cultivation of pearl millet, as far as $15 \mathrm{~km}$ west of the river bank [26,40]. These types of cultivation are visible on satellite images, and temporal series, provided freely by GoogleEarth. However, because the individual plants are widely spaced and a great amount of ground is visible between them, this type of cultivation is practically undetected by automatic systems of vegetation reconstruction. A visual scanning of the satellite images of the area surveyed, and of neighbouring areas where local collaborators had additional fields, suggested that this type of practice, though highly variable and uncertain, is viable not only when rainfall is abundant (i.e., around $350 \mathrm{~mm}$ ) but also when its values are much lower than what is considered the minimum required for this crop to grow. Indeed, the observation of temporal series have shown the presence of fields in years when the average rainfall was around $150 \mathrm{~mm}$ ([40] Figure 2). According to the Harvest Choice data [25], the rainfed cultivation of pearl millet in our study area is limited to a small area on the banks of the Nile where it can benefit from seasonal river flooding. The areas that we identified during fieldwork are not included in their maps (Figure 5) and indeed, traditional rainfed cultivation of pearl millet is not recorded in the Khartoum state (where our study area is located) in the latest reports on agricultural productivity in Sudan [51].

Interestingly, although we did not personally visit the area where Harvest Choice places pearl millet rainfed cultivation, in our research we never encountered this crop cultivated on the floodplain of the river. This area is usually cultivated with sorghum and vegetables, making the most of the higher soil moisture and organic content provided by the flooding of the river. The fields of pearl millet are usually located further inland from the Nile, in areas where the soil has lower quantities of organic matter and less moisture. Moreover, ethnographic interviews conducted in this area have revealed that this type of cultivation can provide the farmers with enough crops to cover their annual needs and in times of good rainfall (e.g., above $150 \mathrm{~mm}$ ) even with surplus to sell at the market and the possibility to cultivate cash crops [26,40] (Table 3). 


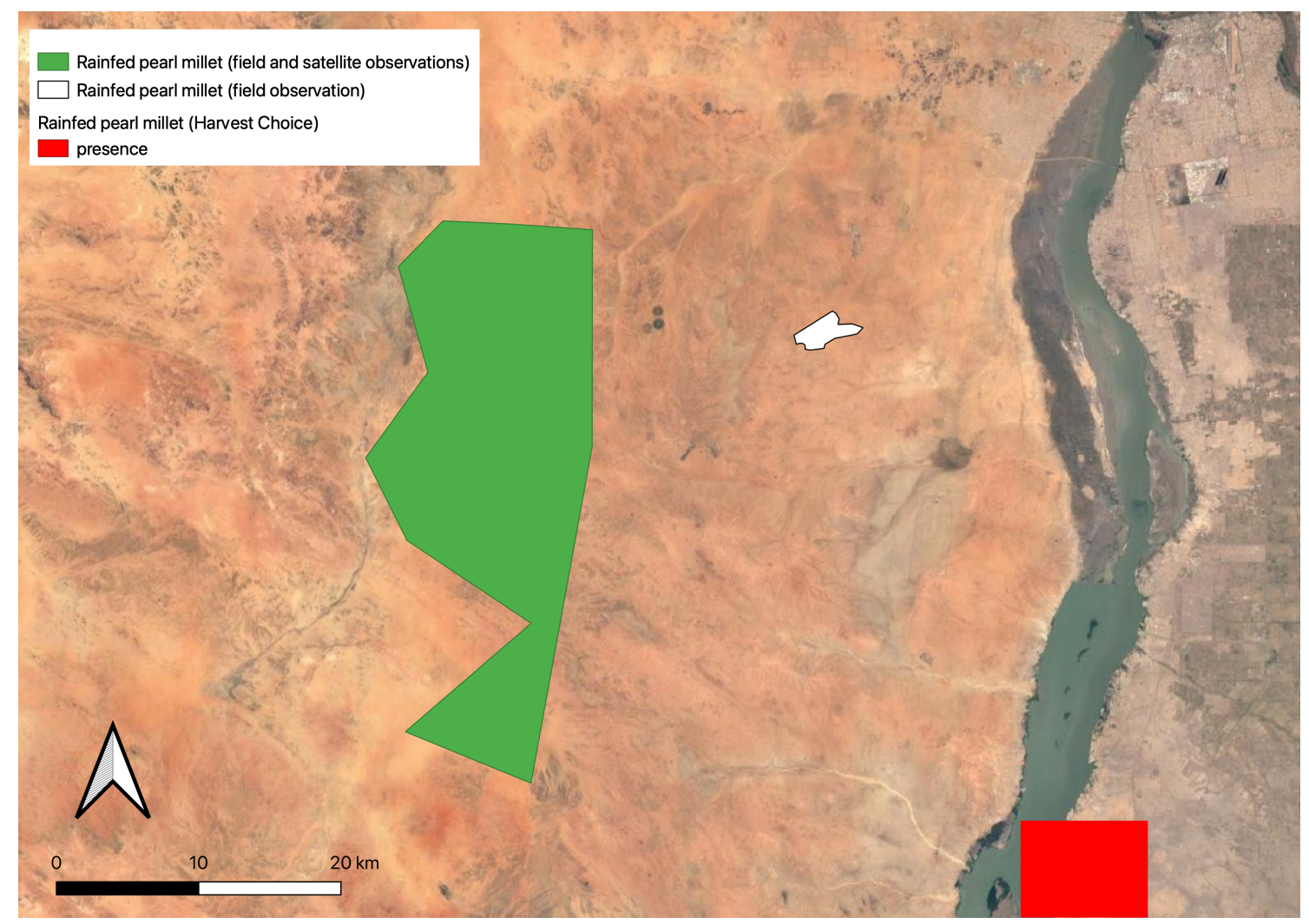

Figure 5. Map showing the location and extent of rainfed pearl millet fields, observed both during ethnographic fieldwork and remotely (map elaborated with QGIS-LTR 3.16, base image GoolgeEarth satellite 2014).

Table 3. Demographic and crop data collected during ethnographic interviews in Central Sudan [26,40] in 2016 and 2019. LU1 = Land Use level 1; LU2 = Land Use level 2; field area is expressed in ha; production of millets only (pearl millet and sorghum) is expressed in $\mathrm{kg}$ and is an estimation based on average plants per area and average production per plant (except in the case marked with *) and on the last 5 years' average production of traditional rainfed cultivation [51].

\begin{tabular}{|c|c|c|c|c|c|c|}
\hline Area & LU1 & LU2 & Field Area & Floodplain & Crop & Production \\
\hline Al Khiday & Agriculture & Herbaceous/ground crops & 16.8 & no & Pearl millet & 1600 \\
\hline Al Khiday & Agriculture & Herbaceous/ground crops & 19.7 & no & Pearl millet & $2000 *$ \\
\hline El Gos & Agriculture & Herbaceous/ground crops & 12.6 & no & Pearl millet & 1260 \\
\hline El Gos & Agriculture & Herbaceous/ground crops & 10 & no & Pearl millet, watermelon & 1000 \\
\hline Atwal & Agriculture & Herbaceous/ground crops & 4.6 & yes & Sorghum, vegetables & 2100 \\
\hline Atwal & Agriculture & Herbaceous/ground crops & 7.6 & yes & Sorghum, vegetables & 3500 \\
\hline Atwal & Agriculture & Herbaceous/ground crops & 16.8 & yes & Sorghum, vegetables & 7700 \\
\hline Samrah & Agriculture & Herbaceous/ground crops & 1.7 & yes & Sorghum, vegetables & 782 \\
\hline Samrah & Agriculture & Herbaceous/ground crops & 6.3 & yes & Sorghum, vegetables & 2900 \\
\hline Samrah & Agriculture & Herbaceous/ground crops & 16.8 & yes & Lady fingers (okra) & nd \\
\hline Samrah & Agriculture & Herbaceous/ground crops & 13.9 & yes & Sorghum, vegetables & 6400 \\
\hline Umm Habib & Agriculture & Herbaceous/ground crops & 2.1 & no & Pearl millet & 2100 \\
\hline Umm Habib & Agriculture & Herbaceous/ground crops & 6.3 & no & Pearl millet, watermelon & 630 \\
\hline
\end{tabular}

\section{Discussion}

The reconstruction of past land use in hyper-arid and arid environments will certainly continue challenging the scientific community for some time. As noted, technological advances, especially in the acquisition of data through remote-sensing, are enabling a better understanding of present and past land use activities. However, there are still many issues that hamper our ability to fully and correctly identify the types of practices discussed in this paper. First and foremost, the meagre remains they leave behind makes it difficult to directly trace their existence far back in the past. With the exception of oasis agriculture, which is geographically tied to features whose presence can be identified in 
the paleoenvironmental record, the trajectories of pastoralism and rainfed agriculture can only be reconstructed through the interpretation of indirect evidence. Both these practices are usually inferred through the analysis of macroscopic, and in a few cases, microscopic archaeological, evidence such as architectural remains, settlement location and bioarchaeological remains, and the contexts in which all these are found is usually what drives their interpretation. Late Holocene occupation evidence (monuments and settlements), widespread from Mauritania's coast to the Nile Valley, have recently been analysed through remote sensing $[32,52,53]$. In spite of the almost total inaccessibility of many regions in North Africa and the Sahara after the 2011 turmoil, large inventories of endangered sites have been and are being compiled, by various international efforts (e.g., the EAMENA project or also the Mapping Africa's Endangered Archaeological Sites and Monuments project). Nonetheless, the majority of available data come from the Fazzan and from the Nile Valley. In these regions, the reconstruction of the archaeological land use of pastoral areas may be inferred by the distribution of archaeological sites unequivocally related to ancient herders (e.g., dung deposits, recognisable burial monuments or material culture linked to ancient pastoral communities), although pastures might have well extended beyond the recorded archaeological evidence [32]. In the "customary" areas considered in this paper inhabited by pastoralists in the 1930s, evidence of past frequentations by herder societies have been noticed in the form of burial tumuli [32,54], archaeological deposits [55,56], rock art [57,58], and the surface scatters of materials [59]. An outstanding dataset of remotely identified sites, selected foot surveys, and dozens of C14 dates has enabled the reconstruction of past human activities within the five areas of the Fazzan discussed above. In Garamantian times, major crops included palm trees, pearl millet, and sorghum $[60,61]$, the latter two apparently absent today according to the spatial allocation model for crops of Harvest Choice [25]. The combination of farming in the oases, pastoralism in the immediate surroundings and in the mountains, and the long distance trans-Saharan trade, allowed the Garamantian kingdom to flourish in the rugged terrains of the Sahara for centuries. The ability to cope with variation in rainfall and, thus, in the exploitation of different ecological niches, was key to enhancing the resilience of past Central Saharan populations during the Late Holocene, up to the present day. In this perspective, the demographic decrease postulated after the end of the AHP [62] may be better read as the concentration around some oases, where most tangible evidence of human frequentations is to be found in the forms of forts [63-65], necropoleis [32,66-69], and oasis fields [7,18]. Not surprisingly, colonial accounts from the 1930s report the existence of ksur (forts) of uncertain date (ranging from the Garamantian to Islamic age) in the oases, testifying to the temporal depth of the human exploitation of such niches. In Central Sudan, the area immediately adjacent to the Nile has provided innumerable examples of successful adaptation to otherwise hyper-arid conditions. The debate on whether southwest Asian cereals, i.e., wheat and barley, were introduced together with domestic animals between the end of the 7 th and the beginning of 6 th millennium BCE, or the two events were separate and sequential, is still ongoing [70]. However, a holistic view of the archaeobotanical remains identified mostly in cemeteries, is slowly pushing the use and consumption of crops such as wheat and barley (C3 plants) to the second half of the 6th millennium BCE (5620-5480 cal BC) [71]. These results are particularly significant as the wild ancestors of these crops are missing from the region [72], which led the authors of the study to suggest that they were imported from the north of the Nile Valley ([71] p. 5). However, they do not exclude the possibility of a local cultivation of these crops that relied on the flooding of the river ([71] p. 6). The widespread presence of phytolith and starch from millets (used in the widest sense to include several types of millet and sorghum, C4 plants), found in the necropolis at Ghaba, also suggests that Neolithic people were consuming a wide spectrum of local cereals [47]. The existence of a broad-spectrum diet is partially confirmed by the stable isotope analysis conducted on human bone remains found at Al Khiday [73], which showed that the diet of pre-Mesolithic people was composed of a mixture of C3 and C4 plants, whereas the Mesolithic diet seems to shift towards C4 species only. It is most likely that the C3 signature of the pre-Mesolithic individuals is derived 
from legumes rather than cereals. Although it was not possible to fully ascertain whether the millets remains recovered from Ghaba pertained to wild or domestic species [71], it was noted that the morphology and patterns of fragmentation of the silica skeletons (phytoliths in anatomical connections) did not follow the natural contour of individual cells [47]. This led the authors of the study to suggest that millets were at least partly processed using a sharp tool but no further indications on whether these were wild or domestic were proposed. Taken together, these findings challenge the traditional interpretation of the Neolithic of the Sudanese Nile Valley as mainly characterised by pastoralism and introduce the presence of domestic cereals from c. 500 years earlier than considered to date [47]. Thus, agriculture had a more important role than previously thought, at least in the Nile Valley. Our ethnographic research, described in Section 3.3, might suggest that alternative methods of cultivation could have coexisted with floodplain agriculture and might offer a hint of whether millets remains found at Ghaba, but also at Kedada [74], could be domestic rainfed plants. Archaeologically, crop water management is usually hypothesised on the basis of geography, economy and the degree of social organisation. Thus, sites that are (or were) located in the vicinity of a major watercourse, such as the Nile, are usually believed to rely on floodplain agriculture. Similarly, when archaeobotanical remains are found in locations that are far from any permanent water source, crops are believed to be grown under rainfed conditions or imported. This is the case, for example, in the recent research by di Lernia and colleagues [75] on the possible presence of rainfed cultivation in the Tadrart Acacus in the past. Advances in the analytical methods available to archaeologists provide a method to infer plant water availability directly from archaeobotanical remains through the application of stable isotope and phytolith analyses (see [26], for a review on the subject). This has been established and widely tested for C3 plants but is still being developed for C4 species. Preliminary results on phytolith extracted from sediments collected in modern fields of rainfed pearl millet in the area of Al Khiday suggest that this could be a viable approach to identify past water management practices for C4 crops [26], but more research is ongoing that will create the necessary baseline values for the study of archaeobotanical remains. The reliable classification of pastoral and agricultural practices in the past is of paramount importance for the reconstruction of past land use scenarios that can be integrated into climate modelling. To this effect, the present research is a first step towards the introduction of different, or more nuanced, models of land use in hyper-arid deserts. This effort is frameworked within the wider context of the LandCover6k action of PAGES [4] and especially the Archaeology/History land use reconstruction group, which aims at providing the climate modelling community with information on past land use reconstructed from archaeological proxies. In particular, this work contributes to a better definition of two land use categories [3]:

1. LU1 agriculture > LU2 herbaceous/ground crops (with variables: "CULTIGEN" = wheat, barley, pulses, sorghum, millets, orchard/trees crops and "WATER AND LANDSCAPE MODIFICATIONS" = rainfed, flood, qanats);

2. LU1 pastoralism > LU2 mobile irregular (with variable: "SETTLEMENT MODE" = dispersed, non sedentary).

\section{Conclusions}

Along with a variety of proxies hinting at a general trend toward aridification in Saharan Africa [8,46], more recent research has remarked the role of local sequences for understanding the responses of landscape units and human communities to climatic shifts $[76,77]$. The available data point to a marked variation in yearly rainfall over the last four millennia, within the context of increasing aridity [78,79]. Human responses to aridification were likely mediated by local geomorphological factors, such as for example, the existence and size of near-surface aquifers or of areas of increased rainwater retention, that enhanced or mitigated the effect of climate change. Moreover, if climatic events are global, "change" is likely experienced in regional or local terms (e.g., the flooding of a given plain, the shrinking of a lake, the reduction in pasture). The ethnographic data provide insights on 
how human societies cope with the available resources and thrive in allegedly unsuitable regions. In this paper, we aimed at re-examining ethnographic and ethnoarchaeological data that represent, in our vision, an overlooked source of information. Often vague and largely descriptive, many ethnographic reports deserve an in-depth analysis to extract valuable facts and figures that can indicate possible land use practices. In this work, we focused on primary sources, i.e., those produced by direct observation in the field, and their role in providing usable data for understanding contemporary and sub-contemporary forms of land use in hyper-arid environments. The data presented in this paper, coupled with a recent review [26] are providing new information on forms of land use that escape traditional views on drylands ecosystems. Rainfed agriculture in hyper-arid and arid areas represent a well-rooted cultivation practice characterised by its sustainability. The use of the scarce and erratic rainfall in drylands for agricultural purposes, in fact, highlights the role of traditional ecological knowledge for food production. In terms of land use, data on oasis cultivation in the Old World drylands are extremely scarce [33]. In this paper, we attempted a first quantification of agricultural production in hyper-arid regions, that may help refine the land use study of similar areas set between North Africa and the Middle East, up to arid areas of South East Asia. Ultimately, the knowledge on agro-pastoral practices, coupled with data on the type and the quantity of livestock and crops, supplement the qualitative information that often characterises the pure ethnographic literature, contributing to a better characterisation of land use in hyper-arid areas, where remote-based modelling does not detect potentially usable lands for pastoral and/or agricultural communities. Data collected in the present can be used to build general models for the interpretation of the past, in a genuine and data-informed ethnoarchaeological perspective, focusing on less evident (or less studied) elements of the drylands' archaeological landscape.

Author Contributions: Both authors have contributed equally to every part of this research from conception to the writing of the paper. All authors have read and agreed to the published version of the manuscript.

Funding: This research and the APC were funded by the European Research Council, grant number ERC-Stg-2017 759800, RAINDROPS project.

Institutional Review Board Statement: The study was conducted according to the guidelines of the Declaration of Helsinki, and approved by the Research Ethics Committee of Parc de Salut Mar (reference number 2017,7662,I, date of approval 31 October 2017)

Informed Consent Statement: Oral informed consent was obtained from all subjects involved in the study.

Acknowledgments: We are deeply indebted to Donatella Usai and Sandro Salavtori for giving us the opportunity to carry out ethnographic fieldwork under their research licence and to NCAM for providing such licence. This work could not have been performed without the support and help of Mongeda Khalid Magzoub and Yassen Ibrahem who accompanied us during our interviews and also collected data for us when we could not visit Sudan. Both authors are members of the research group CaSEs (recognised by AGAUR SGr-212) and this paper has benefited from long and fruitful discussion with all its members, in particular Marco Madella and Abel Ruiz-Giralt. CaSEs is associated unit of the IMF-CSIC. This study was undertaken as part of the Past Global Changes (PAGES) project (and working group LandCover6k), and the Human and Biosphere Commission of INQUA (the Global Holocene Land Use-HoLa-International Focus Group and related projects).Lastly, we want to thank the editors of this volume to invite us to participate in this Special Issue.

Conflicts of Interest: The authors declare no conflict of interest. The funders had no role in the design of tdhe study; in the collection, analyses, or interpretation of data; in the writing of the manuscript, or in the decision to publish the results. 


\section{References}

1. Zomer, R.J.; Bossio, D.A.; Trabucco, A.; Yuanjie, L.; Gupta, D.C.; Singh, V.P. Trees and Water: Smallholder Agroforestry on Irrigated Lands in Northern India; International Water Management Institute: Colombo, Sri Lanka, 2007; Volume 122.

2. Zomer, R.J.; Trabucco, A.; Bossio, D.A.; van Straaten, O.; Verchot, L. Climate Change Mitigation: A Spatial Analysis of Global Land Suitability for Clean Development Mechanism Afforestation and Reforestation. Agric. Ecosyst. Environ. 2008, 126, 67-80. [CrossRef]

3. Morrison, K.; Hammer, E.; Boles, O.; Madella, M.; Whitehouse, N.; Gaillard, M.J.; Bates, J.; Vander Linden, M.; Merlo, S.; Yao, A.; et al. Mapping past human land use using archaeological data: A new classification for global land use synthesis and data harmonization. PLoS ONE 2021, 16, e0246662.. [CrossRef]

4. Gaillard, M.J.; Morrison, K.; Madella, M.; Whitehouse, N. Editorial: Past land-use and land-cover change: The challenge of quantification at the subcontinental to global scales. Past Glob. Chang. Mag. 2018, 26. [CrossRef]

5. Cremaschi, M.; Zerboni, A.; Mercuri, A.M.; Olmi, L.; Biagetti, S.; di Lernia, S. Takarkori rock shelter (SW Libya): An archive of Holocene climate and environmental changes in the central Sahara. Quat. Sci. Rev. 2014, 101, 36-60. [CrossRef]

6. Kuper, R.; Kröpelin, S. Climate-Controlled Holocene Occupation in the Sahara: Motor of Africa's Evolution. Science 2006, 313, 803-807. [CrossRef]

7. Mattingly, D.J.; Merlo, S.; Mori, L.; Sterry, M. Garamantian Oasis Settlements in Fazzan. In Urbanisation and State Formation in the Ancient Sahara and Beyond; Mattingly, D.J., Sterry, M., Eds.; Trans-Saharan Archaeology; Cambridge University Press: Cambridge, UK, 2020; pp. 53-111.

8. DeMenocal, P.; Ortiz, J.; Guilderson, T.; Adkins, J.; Sarnthein, M.; Baker, L.; Yarusinsky, M. Abrupt onset and termination of the African Humid Period: Rapid climate responses to gradual insolation forcing. Quat. Sci. Rev. 2000, 19, 347-361. [CrossRef]

9. Kröpelin, S.; Verschuren, D.; Lézine, A.M.; Eggermont, H.; Cocquyt, C.; Francus, P.; Cazet, J.P.; Fagot, M.; Rumes, B.; Russell, J.M.; et al. Climate-Driven Ecosystem Succession in the Sahara: The Past 6000 Years. Science 2008, 320, 765-768. [CrossRef]

10. Phelps, L.N.; Broennimann, O.; Manning, K.; Timpson, A.; Jousse, H.; Mariethoz, G.; Fordham, D.A.; Shanahan, T.M.; Davis, B.A.S.; Guisan, A. Reconstructing the climatic niche breadth of land use for animal production during the African Holocene. Glob. Ecol. Biogeogr. 2020, 29, 127-147. [CrossRef]

11. di Lernia, S. The emergence and spread of herding in Northern Africa: A critical reappraisal. In Oxford Handbook of African Archaeology; Mitchell, P., Lane, P., Eds.; Oxford University Press: Oxford, UK, 2013; pp. 527-540.

12. Zerboni, A.; Biagetti, S.; Lancelotti, C.; Madella, M. The end of the Holocene Humid Period in the central Sahara and Thar deserts: Societal collapses or new opportunities? PAGES Mag. 2016, 24, 60-61. [CrossRef]

13. Ellis, J.; Swift, D. Stability of African ecosystems: Alternate paradigms and implications for development. J. Range Manag. 1988, $41,450-459$.

14. Scoones, I. Living with Uncertainty; Practical Action Publishing: Rugby, UK, 1995.

15. Wilson, A. Foggaras in Ancient North Africa or How to Marry a Berber Princess. Foggaras Anc. N. Afr. How Marry Berber Princess 2009, 1000-1021. [CrossRef]

16. Biagetti, S. Ethnoarchaeology of the Kel Tadrart Tuareg. Pastoralism and Resilience in Central Sahara; SpringerBriefs in Archaeology; Springer International Publishing: Dordrecht, The Netherlands, 2014.

17. Mattingly, D. (Ed.) The Archaeology of Fazzan.Volume 4, Survey and Excavations at Old Jarma (Ancient Garama) Carried Out by C. M. Daniels (1962-69) and The Fazzan Project (1997-2001); The Society for Libyan Studies: London, UK, 2013.

18. Mattingly, D.J.; Sterry, M. The first towns in the central Sahara. Antiquity 2013, 87, 503-518. [CrossRef]

19. Nabil, M.; Zhang, M.; Bofana, J.; Wu, B.; Stein, A.; Dong, T.; Zeng, H.; Shang, J. Assessing factors impacting the spatial discrepancy of remote sensing based cropland products: A case study in Africa. Int. J. Appl. Earth Obs. Geoinf. 2020, 85, 102010. [CrossRef]

20. Pérez-Hoyos, A.; Rembold, F.; Kerdiles, H.; Gallego, J. Comparison of Global Land Cover Datasets for Cropland Monitoring. Remote Sens. 2017, 9, 1118. [CrossRef]

21. Congalton, R.; Yadav, K.; McDonnell, K.; Poehnelt, J.; Stevens, B.; Gumma, M.; Teluguntla, P.; Thenkabail, P. NASA Making Earth System Data Records for Use in Research Environments (MEaSUREs) Global Food Security-Support Analysis Data (GFSAD) Cropland Extent 2015 Validation Global 30 m V001; USGS EROS: Sioux Falls, SD, USA, 2017.

22. Fritz, S.; See, L.; Bayas, J.C.L.; Waldner, F.; Jacques, D.; Becker-Reshef, I.; Whitcraft, A.; Baruth, B.; Bonifacio, R.; Crutchfield, J.; et al. A comparison of global agricultural monitoring systems and current gaps. Agric. Syst. 2019, 168, 258-272. [CrossRef]

23. FAO. FAO Statistical Pocketbook; FAO: Rome, Italy, 2015.

24. Yu, Q.; You, L.; Wood-Sichra, U.; Ru, Y.; Joglekar, A.K.B.; Fritz, S.; Xiong, W.; Lu, M.; Wu, W.; Yang, P. A cultivated planet in 2010-Part 2: The global gridded agricultural-production maps. Earth Syst. Sci. Data 2020, 12, 3545-3572. [CrossRef]

25. International Food Policy Research Institute. Spatially-Disaggregated Crop Production Statistics Data in Africa South of the Sahara for 2017. 2020. Available online: https:/ / doi.org/10.7910/DVN/FSSKBW (accessed on 20 March 2021).

26. Lancelotti, C.; Biagetti, S.; Zerboni, A.; Usai, D.; Madella, M. The archaeology and ethnoarchaeology of rain-fed cultivation in arid and hyper-arid North Africa. Antiquity 2019, 93, 1026-1039; doi:10.15184/aqy.2019.109. [CrossRef]

27. Phelps, L.N.; Kaplan, J.O. Land use for animal production in global change studies: Defining and characterizing a framework. Glob. Chang. Biol. 2017, 23, 4457-4471. [CrossRef]

28. Bartholomé, E.; Belward, A.S. GLC2000: A new approach to global land cover mapping from Earth observation data. Int. J. Remote Sens. 2005, 26, 1959-1977. [CrossRef] 
29. Arino, O.; Ramos Perez, J.J.; Kalogirou, V.; Bontemps, S.; Defourny, P.; Van Bogaert, E. Global Land Cover Map for 2009 (GlobCover 2009); European Space Agency (ESA): Paris, France, 2012. [CrossRef]

30. Ramankutty, N.; Evan, A.T.; Monfreda, C.; Foley, J.A. Farming the planet: 1. Geographic distribution of global agricultural lands in the year 2000. Glob. Biogeochem. Cycles 2008, 22. [CrossRef]

31. Ellis, E.C.; Goldewijk, K.K.; Siebert, S.; Lightman, D.; Ramankutty, N. Anthropogenic transformation of the biomes, 1700 to 2000. Glob. Ecol. Biogeogr. 2010, 19, 589-606. [CrossRef]

32. Biagetti, S.; Merlo, S.; Adam, E.; Lobo, A.; Conesa, F.C.; Knight, J.; Bekrani, H.; Crema, E.R.; Alcaina-Mateos, J.; Madella, M. High and Medium Resolution Satellite Imagery to Evaluate Late Holocene Human-Environment Interactions in Arid Lands: A Case Study from the Central Sahara. Remote Sens. 2017, 9, 351. [CrossRef]

33. Klein Goldewijk, C. A Historical Land Use Data Set for the Holocene; HYDE 3.2 (Replaced); Data Archiving and Networked Services (DANS): Amsterdam, The Netherlands, 2016.

34. Ellis, E.C.; Ramankutty, N. Putting people in the map: Anthropogenic biomes of the world. Front. Ecol. Environ. 2008, 6, 439-447. [CrossRef]

35. Scarin, E. Nomadi e seminomadi del Fezzan. In Il Sahara Italiano. Fezzan e Oasi di Gat. Parte Prima; Italiana, R.S.G., Ed.; Società Italiana Arti Grafiche: Roma, Italy, 1937; pp. 518-590.

36. Scarin, E. Le oasi del Fezzan; Zanichelli: Bologna, Italy, 1934.

37. Gigliarelli, U. Il Fezzàn; Rapporti e Monografie Coloniali; Governo della Tripolitania, Ufficio Studi: Roma, Italy, $1932 ;$ Volume 1.

38. Mordini, A. Etnografia e fatti culturali. In Il Sahara Italiano. Fezzan e Oasi di Gat. Parte Prima; Italiana, R.S.G., Ed.; Società Italiana Arti Grafiche: Roma, Italy, 1937; pp. 449-491.

39. Despois, J. Mission Scientifique du Fezzan (1944-1946). III: Geographie Humaine; Institut de Recherches Sahariennes, Université d'Alger: El Djazair, Alger, 1946.

40. Biagetti, S.; Ruiz-Giralt, A.; Madella, M.; Khalid Magroub, M.; Meresa, Y.; Haile Gebreselassie, M.; Vesaar, G.M.; Alam Abro, T.; Chandio, A.; Lancelotti, C. No rain no grain? Ethnoarchaeology of sorghum and millets cultivation in drylands. Ethnoarchaeology, unpublished materials.

41. Haaland, R.; Haaland, G. Early Farming Societies Along the Nile. In The Oxford Handbook of African Archaeology; Mitchell, P., Lane, P., Eds.; Oxford University Press: Oxford, UK, 2013; pp. 541-553.

42. Ginter, B.; Kozlowski, J. Kulturelle und palaoklimatische sequencz in der Fayum Depression: Ein zusammenfassende Darstellung der Forschungsarbeiten in der Jahren 1979-1981. Mitteilungen Des Dtsch. Archaol. Instituts Abt. Kairo 1986, 42, 9-23.

43. Arkell, A. Esh Shaheinab; Oxford University Press: Oxford, UK, 1953.

44. Winchell, F.; Brass, M.; Manzo, A.; Beldados, A.; Perna, V.; Murphy, C.; Stevens, C.; Fuller, D.Q. On the Origins and Dissemination of Domesticated Sorghum and Pearl Millet across Africa and into India: A View from the Butana Group of the Far Eastern Sahel. Afr. Archaeol. Rev. 2018, 35, 483-505. [CrossRef] [PubMed]

45. Fuller, D.Q. Early Kushite agriculture: Archaeobotanical evidence from Kawa. Sudan Nubia 2004, 8, 70-74.

46. Hoelzmann, P.; Gasse, F.; Dupont, L.M.; Salzmann, U.; Staubwasser, M.; Leuschner, D.C.; Sirocko, F. Palaeoenvironmental changes in the arid and subarid belt (Sahara-Sahel-Arabian peninsula) from $150 \mathrm{kyr}$ to present. In Past Climate Variability Through Europe and Africa; Springer Netherlands: Dordrecht, The Netherlands, 2004; pp. 219-256.

47. Out, W.A.; Ryan, P.; García-Granero, J.J.; Barastegui, J.; Maritan, L.; Madella, M.; Usai, D. Plant exploitation in Neolithic Sudan: A review in the light of new data from the cemeteries R12 and Ghaba. Quat. Int. 2016, 412, 36-53. [CrossRef]

48. Chapelle, J. Black Nomads of the Sahara; Human Relations Area Files: New Haven, CT, USA, 1982.

49. Allen, R.; Smith, M.; Pereira, L.; Pruitt, W. Proposed revision to the FAO procedure for estimating crop water requirements. In Proceedings of the II International Symposium on Irrigation of Horticultural Crops 449, Chania, Greece, 8-13 September 1996; pp. 17-34.

50. Usai, D.;Salvatori, S. The Mesolithic period on the White Nile region and the al-Khiday sites. Azania Archaeol. Res. Afr.2019, 54, 445-467. [CrossRef]

51. FAO. Special Report-2019 FAO Crop and Food Supply Assessment Mission to the Sudan; FAO: Rome, Italy, 2020.

52. Elfadaly, A.; A. R. Abouarab, M.; M. El Shabrawy, R.R.; Mostafa, W.; Wilson, P.; Morhange, C.; Silverstein, J.; Lasaponara, R. Discovering Potential Settlement Areas around Archaeological Tells Using the Integration between Historic Topographic Maps, Optical, and Radar Data in the Northern Nile Delta, Egypt. Remote Sens. 2019, 11, 3039. [CrossRef]

53. Rayne, L.; Bradbury, J.; Mattingly, D.; Philip, G.; Bewley, R.; Wilson, A. From Above and on the Ground: Geospatial Methods for Recording Endangered Archaeology in the Middle East and North Africa. Geosciences 2017, 7, 100. [CrossRef]

54. di Lernia, S.; Manzi, G. (Eds.) Sand, Stones, and Bones: The Archaeology of Death in the Wadi Tanezzouft Valley (5000-2000 BP); Number 3 in AZA Monographs; All'Insegna del Giglio: Firenze, Italy, 2002.

55. Cremaschi, M.; di Lernia, S. The geoarchaeological survey in the central Tadrart Acacus and surroundings (Libyan Sahara). Environment and cultures. In Wadi Teshuinat. Palaeoenvironment and Prehistory in South-Western Fezzan (Libyan Sahara); Cremaschi, M., di Lernia, S., Eds.; CNR: Milano, Italy, 1998; pp. 243-325.

56. Biagetti, S.; di Lernia, S. Holocene deposits of Saharan rock shelters: The case of Takarkori and other sites from the Tadrart Acacus Mts. (SW Libya). Afr. Archaeol. Rev. 2013, 30, 305-338. [CrossRef]

57. Gallinaro, M. Saharan rock art: Local dynamics and wider perspectives. Arts 2013, 2, 350-382. [CrossRef]

58. Guagnin, M. Animal engravings in the central Sahara: A proxy of a proxy. Environ. Archaeol. 2015, 20, 52-65. [CrossRef] 
59. Biagetti, S.; Cancellieri, E.; Cremaschi, M.; Gauthier, C.; Gauthier, Y.; Gallinaro, M.; Zerboni, A.; Di Lernia, S. The Messak Project. Archaeology and heritage management in SW Libya. J. Afr. Archaeol. 2013, 11, 55-74. [CrossRef]

60. Mercuri, A.M.; Bosi, G.; Buldrini, F. Seeds, fruits and charcoal from the Fewet compound. In Life and Death of a Rural Village in Garamantian Times. Archaeological Investigations in the Fewet Oasis (Libyan Sahara); Mori, L., Ed.; Number 6 in AZA Monographs; All'Insegna del Giglio: Firenze, Italy, 2013; pp. 177-190.

61. Pelling, R. Garamantian agriculture and its significance in a wider North African context: The evidence of the plant remains from the Fazzan project. J. N. Afr. Stud. 2005, 10, 397-412. [CrossRef]

62. Manning, K.; Timpson, A. The demographic response to Holocene climate change in the Sahara. Quat. Sci. Rev. 2014, 101, 28-35. [CrossRef]

63. Biagetti, S.; di Lernia, S. Combining intensive field survey and digital technologies: New data on the Garamantian castles of Wadi Awiss, Acacus Mts., Libyan Sahara. J. Afr. Archaeol. 2008, 6, 57-85. [CrossRef]

64. Mattingly, D. Fortifications settlement and domestic architecture. In The Archaeology of Fazzan: Volume 1. Synthesis; Mattingly, D., Ed.; The Society for Libyan Studies: London, UK, 2003; pp. 136-176.

65. Liverani, M. (Ed.) Aghram Nadharif. The Barkat Oasis (Sha 'abiya of Ghat, Libyan Sahara) in Garamantian Times. In $A Z A$ Monographs; All'Insegna del Giglio: Firenze, Italy, 2005; Volume 5.

66. Leschi, L. La Mission scientifique du Fezzàn. Archéoologie. Trav. De L'Institut De Rech. Sahariennes 1945, 3, 183-186.

67. Mattingly, D.; Abduli, H.; Ahmed, M.; Cole, F.; Fenwick, C.; Fothergill, B.; González Rodriguez, M.; Hobson, M.; Khalaf, N.; Lahr, M.; et al. DMP XII: Excavations and Survey of the so-called Garamantian Royal Cemetery (GSC030-031). Libyan Stud. 2011, 42, 89-102. [CrossRef]

68. Mattingly, D.; Macdonald, K. Africa; OUP Oxford: Oxford, UK, 2013; p. 28.

69. Mori, L.; Ricci, F.; Gatto, M.; Cancellieri, E.; Lemorini, C. The excavation of the fewet necropolis. In Life and Death of a Rural Village in Garamantian Times; Mori, L., Ed.; Number 6 in AZA Monographs; All' Insegna Del Giglio: Firenze, Italy, 2013 ; pp. $253-318$.

70. Salvatori, S.; Usai, D. The neolithic and 'Pastoralism'along the Nile: A dissenting view. J. World Prehistory 2019, 32, 251-285. [CrossRef]

71. Madella, M.; García-Granero, J.J.; Out, W.A.; Ryan, P.; Usai, D. Microbotanical Evidence of Domestic Cereals in Africa 7000 Years Ago. PLoS ONE 2014, 9, e110177. [CrossRef] [PubMed]

72. Zohary, D.; Hopf, M.; Weiss, E. Domestication of Plants in the Old World: The Origin and Spread of Domesticated Plants in Southwest Asia, Europe, and the Mediterranean Basin; Oxford University Press: Oxford, UK, 2012.

73. Iacumin, P.; Matteo, A.D.; Usai, D.; Salvatori, S.; Venturelli, G. Stable isotope study on ancient populations of central sudan: Insights on their diet and environment. Am. J. Phys. Anthropol. 2016, 160, 498-518. [CrossRef]

74. Stemler, A. A scanning electron microscopic analysis of plant impressions in pottery from the sites of Kadero, El Zakiab, Um Direiwa and El Kadada. ArchéOlogie Nil Moyen 1990, 4, 87-105.

75. Di Lernia, S.; N'Siala, I.M.; Mercuri, A.M.; Zerboni, A. Land-use and cultivation in the etaghas of the Tadrart Acacus (south-west Libya): The dawn of Saharan agriculture? Antiquity 2020, 94, 580-600. [CrossRef]

76. Lézine, A.M. Timing of vegetation changes at the end of the Holocene Humid Period in desert areas at the northern edge of the Atlantic and Indian monsoon systems. C. R. Geosci. 2009, 341, 750-759. [CrossRef]

77. Gatto, M.C.; Zerboni, A. Holocene supra-regional environmental changes as trigger for major socio-cultural processes in northeastern Africa and the Sahara. Afr. Archaeol. Rev. 2015, 32, 301-333. [CrossRef]

78. Cremaschi, M.; Pelfini, M.; Santilli, M. Cupressus dupreziana: A dendroclimatic record for the middle-late Holocene in the central Sahara. Holocene 2006, 16, 293-303. [CrossRef]

79. Cremaschi, M.; Zerboni, A. Fewet: An oasis at the margins of Wadi Tanezzuft. Life Death Rural. Village Garamantian Times. Arid Zone Archaeol. Monogr. 2013, 6, 7-16. 